\title{
Aktivitas Penghambatan Ekstrak Etanol Daun Cassia Spectabilis Terhadap Pertumbuhan Plasmodium falciparum dan Plasmodium berghei
}

Wiwied Ekasari ${ }^{l}$, Nindya Tresiana $P^{l}$, Suciati ${ }^{l}$, Tutik Sri Wahyuni ${ }^{l}$, Heny Arwaty ${ }^{2}$

${ }^{1}$ Pharmacognosy and Phytochemistry Departement, Faculty of Pharmacy, Universitas Airlangga, Surabaya

${ }^{2}$ Parasitology Department, Faculty of Medicine, Universitas Airlangga, Surabaya

*Corresponding author: wiwiedeka@ hotmail.com

\begin{abstract}
Background: Antimalarial screening against nine species of the genus Cassia showed that the methanol extract of leaves Cassia spectabilis have the highest activity. Since it will be used as a traditional medicine, hence it is needed further studies of antimalarial activity of these plants by choosing a safer solvent, namely ethanol. Objective: In vitro anti-malarial activity against Plasmodium falciparum was conducted using the method of Trager and Jensen. Methods: The serial solution tested were: 100, 10, 1, 0.1 and $0.01 \mu \mathrm{g} / \mathrm{mL}$, while the in vivo test was performed based on Peter's test (The days suppressive test) that using P. berghei (strain ANKA) infected mice. Results: The results showed that ethanolic extract of $C$. spectabilis leaves has inhibitory activity against $P$. falciparum with $I C_{50}$ value of $12.52 \mu \mathrm{g} / \mathrm{mL}$ and against P. berghei with $E D_{50}$ value of $131.5 \mathrm{mg} / \mathrm{kg}$ body weight. Conclusions: A further study to see the potential of ethanol extract from $C$. Spectabilis leaves as anti-malaria is warranted.
\end{abstract}

Keywords: C. spectabilis, Antimalarial, P. falciparum, P. berghei

\begin{abstract}
Abstrak
Latar belakang: Hasil skrining antimalaria terhadap sembilan spesies dari genus daun Cassia menunjukkan bahwa ekstrak metanol daun C.spectabilis memiliki aktivitas yang terbesar. Karena akan digunakan sebagai obat tradisional, maka dilakukan penelitian lebih lanjut terhadap aktivitas antimalaria dari tanaman ini memilih pelarut yang lebih aman, yaitu etanol. Pengujian aktivitas penghambatan terhadap P. falciparum secara in vitro dilakukan menggunakan metode Trager dan Jensen. Pengujian secara in vitro dilakukan dengan larutan uji seri $100,10,1,0,1$ dan $0,01 \mu \mathrm{g} / \mathrm{mL}$. Sedangkan pengujian antimalaria secara in vivo dilakukan berdasarkan metode Peter yang dilakukan pada mencit terinfeksi $P$. berghei (strain ANKA). Hasil penelitian menunjukkan bahwa ekstrak etanol daun C. spectabilis memiliki aktivitas penghambatan terhadap $P$. falciparum dengan $\mathrm{IC}_{50}$ sebesar $12,52 \mu \mathrm{g} / \mathrm{mL}$ dan terhadap $P$. berghei dengan $\mathrm{ED}_{50}$ sebesar $131,5 \mathrm{mg} / \mathrm{kg}$ BB. Ekstrak etanol daun $C$. spectabilis potensial untuk diteliti lebih lanjut dalam rangka mendapatkan zat aktif antimalaria yang terkandung di dalamnya
\end{abstract}

Kata kunci: C. spectabilis, Antimalarial, P. falciparum, P. berghei 


\section{PENDAHULUAN}

Malaria merupakan salah satu penyakit yang penularannya melalui gigitan nyamuk Anopheles betina, dimana nyamuk tersebut telah terinfeksi protozoa dari genus Plasmodium. Pada 2015 dilaporkan, sekitar 3,2 miliar orang yang berarti hampir setengah dari populasi dunia berisiko terkena malaria. Sebagian besar kasus malaria dan kematian terjadi di sub-Sahara Afrika. Namun, Asia, Amerika Latin, dan pada tingkat lebih rendah Timur Tengah dan sebagian Eropa, juga berisiko. Dilaporkan juga 97 negara dan wilayah saat ini sedang berlangsung transmisi malaria (WHO, 2015).

Pemberantasan penyakit malaria makin menjadi problem dengan timbulnya resistensi terhadap obat-obat antimalaria yang ada, sehingga penemuan antimalaria baru baik dari bahan alam maupun sintesis masih terus diupayakan (Sjafruddin et al, 2004; Kim and Schneider, 2013)

Berdasar hasil uji pendahuluan aktivitas antimalaria ekstrak metanol dari daun sembilan tanaman genus Cassia yaitu C. moschata, C. javanica, C. grandis, $C$. spectabilis, C. multijuga, C. tora, C. Alata, C. garettiana, dan $C$. fistula didapatkan hasil bahwa daun $C$. spectabilis terbukti paling aktif (Ekasari et al., 2015). Untuk dapat digunakan sebagai obat tradisional, ekstrak yang digunakan haruslah berasal dari pelarut yang tergolong aman. Untuk itu dalam upaya pencarian bahan obat tradisional baru sebagai antimalaria, pada penelitian ini akan dilakukan pengujian aktivitas penghambatan daun $C$, spectabilis terhadap pertumbuhan $P$. falciparum in vitro dan $P$. berghei in vivo menggunakan ekstrak etanol.

\section{BAHAN DAN METODE}

\section{Bahan Penelitian}

Bahan Tanaman: Daun C. Spectabilis yang diperoleh dan dideterminasi di Kebun Raya Purwodadi, Jawa Timur.

\section{Parasit Uji}

In vitro: $P$. falciparum yang digunakan adalah biakan P. falciparum strain 3D7 yang dibiakkan dengan metode Trager and Jensen (1976).

In Vivo: Plasmodium berghei strain ANKA yang berasal dari Lembaga Biologi Molekuler Eijkman, Jakarta dan dikembangbiakkan di laboratorium hewan Fakultas Farmasi Universitas Airlangga, Surabaya melalui kultivasi pada mencit.

\section{Hewan Coba}

Hewan coba yang digunakan dalam penelitian ini adalah mencit jantan galur Balb-C yang didapat dari Pusat Veterinaria Farma (Pusvetma) Surabaya. Mencit yang digunakan adalah mencit dengan berat badan 2030 .

\section{Pembuatan Ekstrak daun:}

Serbuk daun daun Cassia sebanyak 50 gram dimaserasi dengan etanol $90 \%$. Selanjutnya filtrat diuapkan dengan menggunakan rotary evaporator (rotavapor) pada suhu $50^{\circ} \mathrm{C}$ hingga diperoleh ekstrak yang kental

\section{Uji Aktivitas Antimalaria : In vitro}

Pengujian aktivitas antimalaria dilakukan menurut modifikasi Budimulja, et al (1997). Mulanya dibuat larutan induk dalam DMSO dan dibuat serial konsentrasi dengan medium komplet ( RPMI 1640 yang diperkaya dengan 10\% plasma, 25mM HEPES dan $25 \mathrm{mM}$ $\mathrm{NaHCO}_{3}$ ) sampai konsentrasi dalam sumuran menjadi $100 ; 10 ; 1 ; 0,1$ dan $0,01 \mu \mathrm{g} / \mathrm{ml}$. Kultur dibuat dengan hematokrit $5 \%$ dan parasitemia sebesar $1 \%$. Setelah diinkubasi selama 48 jam, kultur dipanen dan dibuat hapusan tipis dengan pewarnaan larutan Giemsa. Selanjutnya dihitung persen parasitemia dalam 5000 eritrosit dan dianalisis menggunakan analisis probit sehingga didapatkan harga $\mathrm{IC}_{50}$ (Fidock et al., 2004).

\section{In Vivo}

Mencit yang digunakan dalam penelitian ini dibagi menjadi 7 kelompok yaitu kelompok kontrol negatif dan kelompok uji dengan suspensi ekstrak etanol $90 \%$ daun C. spectabilis. Untuk kelompok kontrol negatif diberi CMC Na 0,5\% dengan pemberian satu kali sehari secara per oral. Untuk kelompok suspensi ekstrak etanol $90 \%$ daun $C$. spectabilis diberi dosis sebesar 50, 75, 100, 150, 200 dan $250 \mathrm{mg} / \mathrm{kg}$ BB mencit dengan pemberian satu kali sehari secara per oral.

Penelitian uji aktivitas antimalaria secara invivo ini menggunakan modifikasi metode Peter (Philipson, 1991), the 4-day supressive test of blood schizontocidal. Pengujian dilakukan dengan pemberian larutan uji selama 4 hari berturut-turut, pengujian selama 4 hari merupakan standard skrining obat antimalaria. Setiap hari diambil hapusan darah dari ekor mencit dan diberi 
pewarnaan Giemsa 15\%. Setelah itu dihitung dengan mikroskop per 5000 eritrosit.

\section{HASIL DAN PEMBAHASAN}

\section{Uji Aktivitas antimalaria In vitro}

Hasil uji aktivitas antimalaria ekstrak etanol daun $C$. spectabilis dapat dilihat pada tabel berikut ini:

Tabel 1. Persen pertumbuhan, Persen penghambatan dan Harga $\mathrm{IC}_{50}$ ekstrak etanol daun $C$. spectabilis terhadap pertumbuhan $P$. falciparum setelah diinkubasi 48 jam

\begin{tabular}{|c|c|c|c|c|c|c|c|c|}
\hline \multirow{2}{*}{$\begin{array}{l}\text { Kons } \\
(\mu \mathrm{g} / \mathrm{mL})\end{array}$} & \multirow[t]{2}{*}{$\mathrm{R}$} & \multicolumn{4}{|c|}{$\%$ Parasitemia } & \multirow{2}{*}{$\begin{array}{c}\% \\
\text { Pertumbuhan } \\
\text { rata-rata }\end{array}$} & \multirow{2}{*}{$\begin{array}{c}\% \\
\text { Hambatan } \\
\text { rata-rata }\end{array}$} & \multirow{2}{*}{$\begin{array}{c}\mathrm{IC}_{50} \\
(\mu \mathrm{g} / \mathrm{mL})\end{array}$} \\
\hline & & 0 jam & Rata-rata & 48 jam & rata-rata & & & \\
\hline \multirow{2}{*}{$\begin{array}{c}\text { Kontrol } \\
\text { neg }\end{array}$} & 1 & 0,38 & \multirow{2}{*}{0,41} & 3,78 & & \multirow{2}{*}{3,36} & \multirow{2}{*}{-} & \multirow[t]{11}{*}{12,52} \\
\hline & 2 & 0,43 & & 3,76 & 3,11 & & & \\
\hline \multirow{2}{*}{100} & 1 & 0,38 & \multirow{2}{*}{0,41} & 0,92 & 094 & \multirow{2}{*}{0,53} & \multirow{2}{*}{84,23} & \\
\hline & 2 & 0,43 & & 0,96 & & & & \\
\hline \multirow{2}{*}{10} & 1 & 0,38 & \multirow{2}{*}{0,41} & 2,60 & 267 & \multirow{2}{*}{2,26} & \multirow{2}{*}{32,74} & \\
\hline & 2 & 0,43 & & 2,74 & & & & \\
\hline \multirow[t]{2}{*}{1} & 1 & 0,38 & \multirow{2}{*}{0,41} & 2,86 & 2,89 & \multirow{2}{*}{2,48} & \multirow{2}{*}{16,19} & \\
\hline & 2 & 0,43 & & 2,92 & & & & \\
\hline 0,1 & 1 & 0,38 & 0,41 & 3,12 & 3,18 & 2,77 & 17,56 & \\
\hline \multirow[b]{2}{*}{0,01} & $\begin{array}{l}2 \\
1\end{array}$ & $\begin{array}{l}0,43 \\
0,38\end{array}$ & \multirow[b]{2}{*}{0,41} & 3,51 & & \multirow[b]{2}{*}{3,04} & \multirow[b]{2}{*}{9,52} & \\
\hline & 2 & 0,43 & & 3,39 & 3,45 & & & \\
\hline
\end{tabular}

\section{Hasil Uji Aktivitas antimalaria in vivo}

Hasil uji aktivitas antimalaria in vivo terhadap ekstrak etanol 90\% daun C. spectabilis dapat dilihat pada tabel 2 dibawah ini:

Tabel 2. Tingkat parasitemia rata-rata mencit terinfeksi $P$. berghei pada pemberian suspensi ekstrak etanol $90 \%$ daun $C$. spectabilis per oral

\begin{tabular}{cccccc}
\hline $\begin{array}{c}\text { Kelompok dosis uji } \\
\text { (mg bahan/kg BB } \\
\text { mencit) }\end{array}$ & $\mathrm{D}_{0}$ & $\mathrm{D}_{1}$ & $\mathrm{D}_{2}$ & $\mathrm{D}_{3}$ & $\mathrm{D}_{4}$ \\
\hline $\mathrm{K}(-)$ & 1,22 & 5,24 & 5,59 & 16,54 & 21,77 \\
50 & 1,57 & 3,28 & 6,57 & 11,15 & 15,74 \\
75 & 2,11 & 3,83 & 6,02 & 10,93 & 15,85 \\
100 & 1,88 & 4,35 & 7,49 & 10,48 & 13,47 \\
150 & 1,30 & 4,34 & 5,73 & 7,11 & 11,29 \\
200 & 1,26 & 3,95 & 4,69 & 8,16 & 9,89 \\
250 & 0,51 & 2,51 & 4,64 & 5,92 & 6,90 \\
\hline
\end{tabular}

Keterangan:

$\mathrm{D}_{0}-\mathrm{D}_{4} \quad$ : Pengamatan persen parasitemia hari ke-0 (sebelum diberi bahan uji sampai hari ke-4 (satu hari setelah bahan uji dihentikan),

$\mathrm{K}(-) \quad$ : kelompok yang diberi suspensi CMC-Na 0,5\% sebagai kontrol negatif

Tabel 3. Persen pertumbuhan dan penghambatan parasit pada mencit terinfeksi P. berghei yang diberi ekstrak etanol $90 \%$ daun $C$. spectabilis per oral

Kelompok dosis uji (mg bahan/kg BB mencit)
Pertumbuhan parasit (\%) Penghambatan parasit (\%)

$\begin{array}{cc}20,55 & - \\ 14,17 & 31,05 \pm 15,82 \\ 13,74 & 33,13 \pm 17,26 \\ 11,59 & 43,60 \pm 29,56 \\ 10,54 & 51,38 \pm 12,58 \\ 8,62 & 58,04 \pm 10,59 \\ 6,39 & 68,91 \pm 8,84\end{array}$


Dari data yang diperoleh pada Tabel 3 diperoleh nilai $\mathrm{ED}_{50}$ dengan menggunakan analisis probit sebesar $131,5 \mathrm{mg} / \mathrm{kg}$ BB mencit.

Penelitian mengenai $C$. spectabilis ini merupakan lanjutan dari hasil penelitian sebelumnya mengenai uji pendahuluan aktivitas antimalaria daun sembilan tanaman genus Cassia yaitu C. moschata, C. javanica, $C$. grandis, C. spectabilis, C. multijuga, C. tora, C. Alata, C. garettiana, dan $C$. fistula yang menggunakan ekstrak metanol (Ekasari et al., 2015). Diketahui bersama untuk dapat digunakan sebagai obat tradisional, ekstrak yang digunakan haruslah berasal dari pelarut yang tergolong aman. Untuk itu pada penelitian kali ini digunakan ekstrak etanol daun $C$. spectabilis yang akan diuji aktivitasnya dalam menghambat pertumbuhan $P$. falciparum in vitro dan $P$. berghei In vivo dalam upaya pencarian aktivitas antimalaria tanaman ini secara menyeluruh.

Pengujian aktivitas antimalaria dalam penelitian ini dilakukan secara in vitro terhadap kultur P. falciparum strain 3D7 yang dibiakkan secara berkesinambungan dengan metode Trager dan Janssen (1976). Pengujian dilakukan dengan menambahkan ekstrak etanol daun $C$. spectabilis ke dalam sumur uji yang telah berisi media lengkap. Kemudian dimasukkan suspensi parasit sebanyak 500uL. Sehingga didapatkan konsentrasi larutan uji sebesar $100 \mathrm{ug} / \mathrm{mL}, 10 \mathrm{ug} / \mathrm{mL}, 1 \mathrm{ug} / \mathrm{mL}, 0,1$ $\mathrm{ug} / \mathrm{mL}, 0,01 \mathrm{ug} / \mathrm{mL}$. Setelah diinkubasi selama 48 jam, mengikuti siklus aseksual parasit, dilakukan panen dengan membuat hapusan tipis dan diwarnai dengan Giemsa (Fidock et al., 2004) Hasil uji in vitro etanol daun $C$. spectabilis terhadap penghambatan pertumbuhan $P$. falciparum didapatkan harga $\mathrm{IC}_{50}$ sebesar 12,52 $\mathrm{ug} / \mathrm{mL}$.

Menurut Oliveira et al. (2009) ekstrak yang memiliki nilai $\mathrm{IC}_{50} \leq 50$ terhadap $P$. falciparum dapat dilanjutkan untuk dilakukan isolasi untuk mendapatkan senyawa aktif antimalaria dari tanaman obat. Ekstrak yang menunjukkan hasil yang baik ini juga disarankan untuk dilanjutkan aktivitas antimalarianya secara in vitro. Dengan demikian menurut batasan tersebut, ekstrak etanol daun C. spectabilis dengan nilai $\mathrm{IC}_{50}$ sebesar 12,52 $\mathrm{ug} / \mathrm{mL}$ memiliki aktivitas yang tinggi sebagai antimalaria.

Selanjutnya pada ekstrak etanol daun C. spectabilis ini dilakukan uji aktivitas penghambatannya secara in vivo pada $P$. berghei. .Pemilihan dosis berdasarkan pada penelitian yang dilakukan Munoz et al. (2000) dimana peneliti menggunakan dosis hingga $1000 \mathrm{mg} / \mathrm{kg}$ BB mencit.Namun agar dapat memenuhi syarat sebagai antimalaria yang aktif dengan harga $\mathrm{ED}_{50}$ dibawah 250 $\mathrm{mg} / \mathrm{kg}$, maka dipilih dosis dengan rentang $50-250 \mathrm{mg} / \mathrm{kg}$ BB mencit. Dari hasil penelitian terlihat rata-rata persen penghambatan terhadap $P$. berghei dari kelompok kontrol negatif dan kelompok uji, dimana semakin besar dosis uji yang diberikan, maka semakin kecil persen pertumbuhan $P$. berghei.Hal ini menunjukkan bahwa semakin besar pula persen penghambatan ekstrak etanol $90 \%$ daun C. spectabilis terhadap pertumbuhan $P$. berghei. Dosis uji $250 \mathrm{mg} / \mathrm{kg}$ memberikan efek penghambatan terbesar $(68,91 \%)$ dibandingkan dengan kelompok dosis uji lainnya. Sehingga dapat dikatakan bahwa ekstrak etanol $90 \%$ daun C. spectabilis memiliki aktivitas antimalaria yang baik karena pada dosis 250 $\mathrm{mg} / \mathrm{kg} / \mathrm{hari}$ menunjukkan persen penghambatan parasit lebih besar dari 50\% (Munoz et al., 2000). Pustaka lainnya (Bantie et al, 2014), menyebutkan bahwa ekstrak yang menghasilkan persentase penghambatan $\geq 50 \%$ dengan uji in vivo pada dosis 500; 250 dan $100 \mathrm{mg} / \mathrm{kgbb}$ diklasifikasikan mempunyai aktivitas antiplasmodium sedang, baik dan sangat baik. Berdasarkan klasifikasi Bantie et al. (2014) maka aktivitas ekstrak etanol daun $C$. spectabilis secara in vivo dapat digolongkan baik karena pada dosis $150 \mathrm{mg} / \mathrm{kg}$ bb sudah dapat menghambat pertumbuhan $P$. berghei $\geq 50 \%$. Sedangkan dengan perhitungan analisis probit didapat harga $\mathrm{ED}_{50}$ dari ekstrak etanol daun C. spectabilis sebesar 131,5 mg/kg.

Hasil keseluruhan diatas menunjukkan bahwa ekstrak etanol $90 \%$ daun C. spectabilis secara in vitro dan in vivo mempunyai aktivitas yang baik sebagai antimalaria yang dapat dijadikan obat antimalaria alternatif atau sebagai pengkombinasi dengan antimalaria lain.

\section{KESIMPULAN}

Ekstrak etanol daun C. spectabilis potensial untuk diteliti lebih lanjut dalam rangka mendapatkan zat aktif antimalaria yang terkandung di dalamnya.

\section{UCAPAN TERIMAKASIH}

Penelitian ini bagian dalam rangkaian proyek penelitian yang didanai oleh Dirjen Pendidikan Tinggi Republik Indonesia. 


\section{DAFTAR PUSTAKA}

Bantie L, Assefa S, Teklehaimanot T, Engidawork E, 2014. In vivo antimalarial activity of the crue leaf extract and solvent fractions of Croton macrostachyus Hocsht. (Euphorbiaceae) against P. berghei in mice. BMC Complement Altern Med 14:79

Budimulja AS, Syaruddin, Tapchaisri P, Wilairat P, Marzuki S. 1997. The Sensitivity of Plasmodium protein synthesis to prokaryotic ribosomal inhibitors. Mol. Biochem Parasitol 84 (1): 137-41

Ekasari W, Wahyuni TS, Yuistira R.A.S. 2015. Potensi antimalaria dan pemeriksaan Mikroskopikfitokimia Genus Cassia. Jurnal Farmasi dan Ilmu Kefarmasian Vol 2.No2. Des .

Fidock DA, Rosenthal PJ, Croft SL, Brun R, Nwaka S, 2004. Antimalarial drug discovery : Efficacy models for compound screening, Review, Nature 3 (Juni): 509-520.

Kim Y, Schneider KA. 2013. Evolution of drug resistance in malaria parasite population. Nat Educ Knowl 4 (8):6

Munoz V, Sauvin M, Bourdy G, Callapa J, Rojas I, Vargas L, Tae A, Deahro E. 2000. The search for natural bioactive compounds through a multidisciplinary approach in Bolivia. Part II. Antimalarial activity of some plants used by Mosetene Indians. J. Ethnopharmacology Vol 69. pp.139-155

Oliveira AB, Dolabela MF, Braga CF, Jacome R LRP, Varotti FP, Povoa MM. 2009. Plant-Derived Antimalarial Agents: New Leads and Efficient Phytomedicines. Part I. Alkaloid. An. Acad. Bras. Ciênc. vol.81 no.4 Dec.

Phillipson, J. David, 1991. Assays for Antimalarial and Amoebicidal Activities. In: Methods In Plant Biochemistry, Vol. 6, pp. 135-141

Sjafruddin D, Siregar JE, Asih PBS, 2004. Antimalarial drug resistance in Indonesia: A molecular analysis. Symposium of malaria control in Indonesia, Proceeding. TDC Airlangga University, Surabaya.

Trager, W.and Jensen, J.B., 1976, Human Malaria parasites in continous culture In: Science, 193, pp. 673-676.

WHO, Malaria, Oktober 2015, www.who.int/ mediacentre/factsheets/fs094/en/ Diakses 21 Desember 2015. Pukul.13.05 WIB 